\title{
COMPETITIVE ABILITY OF BEAN CULTIVARS WITH HAIRY BEGGARTICKS ${ }^{1}$
}

\author{
LEANDRO GALON ${ }^{2}$, RICARDO TREVISOL ${ }^{2}$, CESAR TIAGO FORTE ${ }^{2}$, SIUMAR PEDRO TIRONI ${ }^{3}$, FRANCISCO \\ WILSON REICHERT JÚNIOR ${ }^{2}$, ANDRÉ LUIZ RADUNZ ${ }^{3}$
}

\begin{abstract}
Weed interference is a factor that limits the productivity of beans and, among these, hairy beggarticks is one of the main species competing with the crop for environmental resources. Thus, the aim of this study is to evaluate the competitive ability of black bean cultivars (BRS Campeiro, IPR Uirapuru, SCS204 Predileto and BRS Supremo) in the presence of a biotype of hairy beggarticks. The experimental design is a completely randomized block with four replications. Treatments were arranged in a replacement series, consisting of a proportion of the crop and the hairy beggarticks: 100:0; 75:25; 50:50:24:75, and 0:100, which corresponds to 40:0, 30:10, 20:20, 10:30, and 0:40 plant pots ${ }^{1}$. We accomplished competitive analysis through diagrams applied to the replacement series, as well as using relative competitive indices. The leaf area and shoot dry mass were evaluated at 40 days after emergence of the species. There was competition between bean cultivars and hairy beggarticks for the same environmental resources, causing negative interference in the growth of the species, independent of the proportion of plants. Bean cultivars had a lower relative loss by reducing the morphological variables of the hairy beggarticks, thereby demonstrating superiority in its competitive ability in relation to the weed. Interspecific competition is less damaging than intraspecific competition for both species.
\end{abstract}

Keywords: Phaseolus vulgaris. Bidens pilosa. Competitive interaction.

\section{HABILIDADE COMPETITIVA DE CULTIVARES DE FEIJÃO COM PICÃO-PRETO}

\begin{abstract}
RESUMO - A interferência causada pelas plantas daninhas é um dos fatores que limitam a produtividade do feijoeiro e dentre essas destaca-se o picão-preto como uma das principais espécies que competem com a cultura pelos recursos do meio. Assim sendo, objetivou-se com este trabalho, avaliar a habilidade competitiva de cultivares de feijão do tipo preto (BRS Campeiro, IPR Uirapuru, SCS204 Predileto e BRS Supremo) na presença de biótipo de picão-preto. $\mathrm{O}$ delineamento utilizado foi o de blocos casualizados, com quatro repetições. Os tratamentos foram arranjados em série substitutiva e constituíram-se de proporções da cultura e de picão-preto: 100:0; 75:25; 50:50: 24:75 e 0:100, o que corresponde a 40:0, 30:10, 20:20, 10:30 e 0:40 plantas vaso ${ }^{-1}$. A análise da competitividade foi efetuada por meio de diagramas aplicados a experimentos substitutivos, mais uso de índices de competitividade relativa. Avaliou-se a área foliar e a massa seca da parte aérea aos 40 dias após a emergência das espécies. Houve competição pelos mesmos recursos do meio entre as cultivares de feijão e o picão-preto, ocasionando interferência negativa no crescimento das espécies, independentemente da proporção de plantas. As cultivares de feijão apresentaram menor perda relativa ao reduzirem as variáveis morfológicas do picão-preto e demonstram possuir superioridade na habilidade competitiva em relação à planta daninha. A competição interespecífica é menos prejudicial para ambas as espécies envolvidas do que a competição intraespecífica.
\end{abstract}

Palavras Chaves: Phaseolus vulgaris. Bidens pilosa. Interação competitiva.

\footnotetext{
*Corresponding author

${ }^{1}$ Received for publication in 06/07/2016; accepted in 03/05/2017.

Paper extracted from the second author's Scientific Initiation Scholarship, Project Scientific funded by CNPq, FAPERGS and CAPES.

${ }^{2}$ Department of Agronomy, Universidade Federal da Fronteira Sul, Campus Erechim, RS, Brazil; leandro.galon@uffs.edu.br, rii_trevisol@hotmail.com, cesartiagoforte@hotmail.com,chicowrj@gmail.com.

${ }^{3}$ Department of Agronomy, Universidade Federal da Fronteira Sul, Campus Chapecó, SC, Brazil; siumar.tironi@gmail.com, andre.radunz@uffs.edu.br.
} 


\section{INTRODUCTION}

Bean culture has high economic, social and cultural importance for Brazil. However, the productivity of this crop is affected by biotic factors that limit the productive potential of the cultivars and the quality of the grains harvested. In the case of weeds, is the main reason for low productivity (TEIXEIRA et al., 2009) and if no control measures are adopted, losses can be higher than $82 \%$ (KALSING; VIDAL, 2013).

Among the weeds that infest the bean crop, it is worth mentioning the hairy beggarticks (Bidens pilosa) as the one that has caused the most damage in yield and grain quality (CURY et al., 2013; MANABE et al., 2014). The hairy beggarticks interferes negatively in the physiological characteristics of the bean, as in the consumption of $\mathrm{CO}_{2}$, transpiration, stomatal conductance and mainly in the photosynthetic rate (MANABE et al., 2014). This species is also highly competitive by nutrients, which can reduce the nitrogen, phosphorus, and potassium uptake by bean plants (CURY et al., 2013) by more than $50 \%$, thus affecting the quantity and quality of harvested grains.

The most commonly method for the management of weeds in common bean is the chemical, as a function of practicality, efficiency and lower cost when compared to other control methods. However, the use of herbicides can contaminate the environment, the applicator and leave residues in the grains and, in many cases, cause phytotoxicity to the crop itself (CIESLIK; VIDAL; TREZZI, 2014).

Integrated weed management advocates the use of several control methods to control the weed community, with a call to reduce the use of herbicides. The choice of the cultivar that presents greater competitive ability in the presence of weeds may be a management strategy for the crop to present advantages in relation to weeds in the search for resources of the environment (CURY et al., 2013). The bean growth habit may be an attribute that interferes with the competitive ability, because the cultivars with semi-determined and prostrate growth habits present a greater competitive ability with the weed community (TEIXEIRA et al., 2009) compared to cultivars with erect growth habits (ANDRADE et al., 1999). It is noteworthy that the more branched cultivars cover the soil better (types III and III/II) and cause the lower weed infestation in the crop area under shading, highlighting thus the semi-erect and prostrate growth habits (TEIXEIRA et al., 2009).

The competitive dynamics between the crop and the weed community directly interfere with the intensity of the competition. The losses caused by weeds are aggravated when they occur in high population (VIDAL; KALSING; GHEREKHLOO, 2010) being a result of the wide propagules production capacity and survival of seeds in the soil. Knowing the dynamics of weed competitiveness makes it possible to choose appropriate management strategies through the adoption of integrated control methods, since it is possible through studies involving substitutive experiments to define characteristics that confer greater competitive ability between weed species and crops (MUNIER-JOLAIN et al., 2014). The competitive ability is characterized by the dominance of an individual over its neighbors, which simultaneously use the same resource with limited availability (AARSSEN, 1983). Competitive ability can be analyzed for effects under two aspects: suppression of neighbor growth and tolerance to the presence of neighbors (GOLDBERG; LANDA, 1991). The degree of competition depends on factors related to the weed community (species, population, distribution, and season of emergence) and to the crop itself (species or cultivar, line spacing and population). Among the factors related to the weed community, the plant population can be considered one of the most important, so that the larger the population of the weed community, the greater the number of individuals that compete for the same resources of the environment and the more intense will be the competition suffered by the culture (CHRISTOFFOLETI; VICTÓRIA FILHO, 1996). Thus, it is possible to contribute to the sustainable use of environmental resources and to minimize the negative impacts of the use of herbicides for the management of weed infestations.

The hypothesis of the research was that the hairy beggarticks, because it adapts better to the environment than the bean crop, presents a greater competitive ability when it occurs in proportions equal to those of bean cultivars in adequate resource situations. The objective of this work was to evaluate the competitive ability of black bean cultivars (BRS Campeiro, IPR Uirapuru, SCS204 Predileto and BRS Supremo) in hairy beggarticks coexistence.

\section{MATERIAL AND METHODS}

Nine experiments were carried out under greenhouse conditions at the Federal University of the Southern Frontier (UFFS), Campus Erechim / RS, in the 2013/14 SEASON, between the preliminary and additive preliminary tests in a substitutive series. The treatments were implanted in plastic pots with a capacity of $6 \mathrm{dm}^{3}$, filled with latosol (EMBRAPA, 2013). The maintenance fertilization was performed per physicochemical analyzes and followed the recommendations for black bean (ELIAS, 2012). The precipitation and the average temperature conditions in the period of the tests are set forth in Figure 1. 


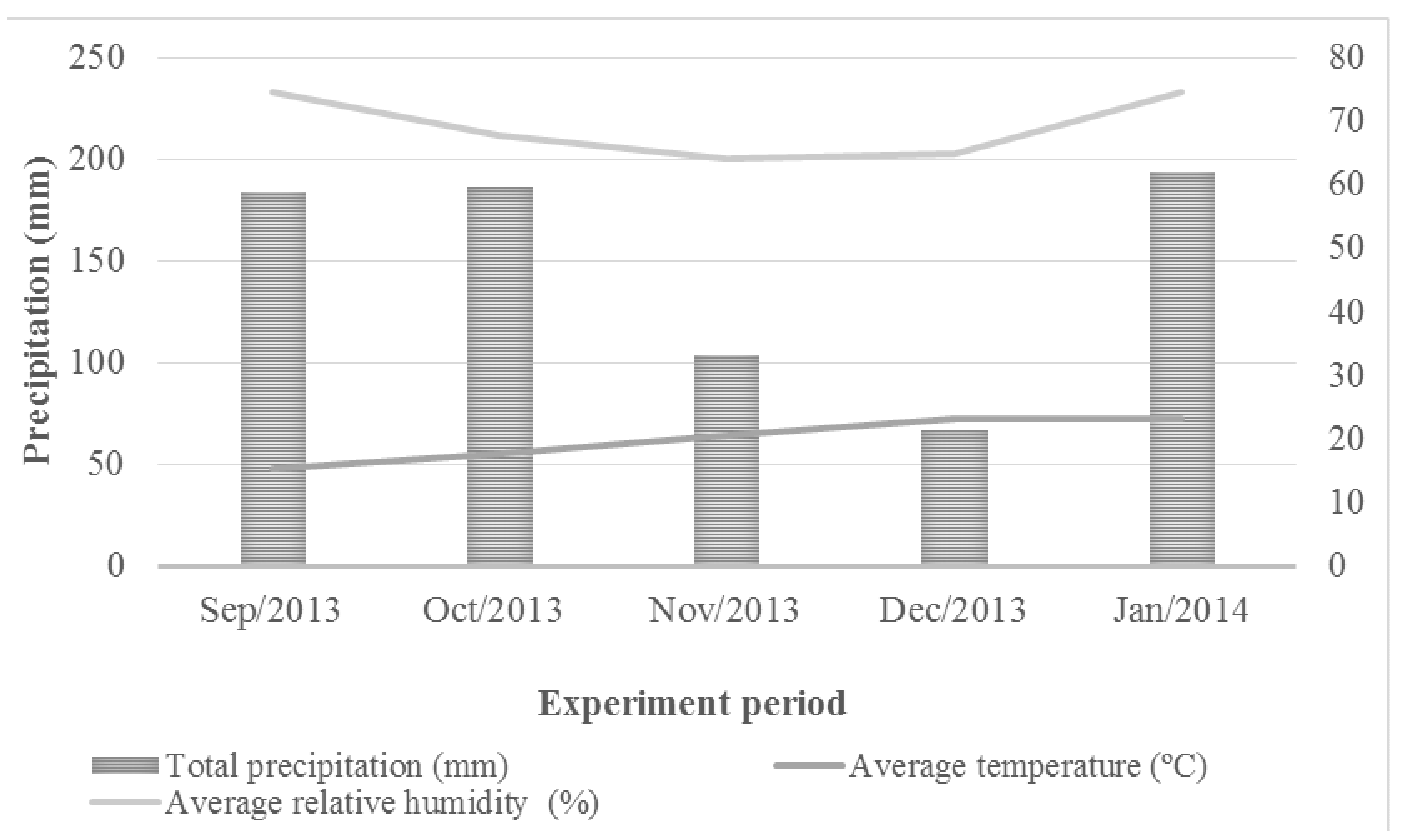

Figure 1. Monthly average rainfall $(\mathrm{mm})$, monthly average temperature $\left({ }^{\circ} \mathrm{C}\right)$ and monthly average relative humidity $(\%)$ in the period of the experiment. Source: Inmet (2017).

The experimental design was completely randomized, with four replications. The tested competitors were black bean cultivars, BRS Campeiro, IPR Uirapuru, SCS204 Predileto and BRS Supremo, which competed with a hairy beggarticks biotype, identified as B. pilosa, the seeds were collected in the experimental area of the UFFS, Câmpus Erechim. The cultivars, BRS Campeiro, IPR Uirapuru and BRS Supremo were selected for sowing in the experiment because they are currently widely used in Brazil for black bean production, and SCS204 Predileto for having been launched in the 2013/14 season by Epagri. The characteristics of the bean cultivars used in the experiment, according to the MAPA (2016), are: 1 - BRS Campeiro - presents an indeterminate growth habit, intermediate type between II and III, semi-precocious cycle (75 to 85 days), erect arquitecture, showed superiority of $32 \%$ in grain yield when compared to the average of the controls in VCU, resistant to lodging and to the common mosaic and intermediate resistance to rust and Fusarium; 2 - BRS Supreme indeterminate growth habit type II, erect, average cycle (83 days), in some VCU research presented $2 \%$ more productivity when compared to controls, resistance to rust, common mosaic and Four pathotypes of the fungus causing anthracnose; 3 - IPR Uirapuru type II indeterminate growth habit, erect, medium cycle (86 days), has a productive potential of $2400 \mathrm{~kg} \mathrm{ha}^{-1}$, resistant to rust, powdery mildew and common mosaic, and SCS204 Predileto shows an indeterminate growth habit Type II, semi-erect, average cycle (89 days), productive potential of $4,400 \mathrm{~kg} \mathrm{ha}^{-1}$, and resistant to some anthracnose races.

Five preliminary experiments were conducted from September to November 2013, both for bean cultivars and for hairy beggarticks in monoculture systems, arranged in an additive series (RADOSEVICH; HOLT; GHERSA, 2007) to determine the plant population so that the final dry mass production is constant. In these, populations of $1,2,4,8,16,24,32,40,48,56$ and 64 plants pot $^{-1}$ (equivalent to $25,49,98,196,392,587,784,980$, $1,176,1,372$ and 1,568 plants $\mathrm{m}^{-2}$ ). The final production was obtained with a mean population of 40 plants pot $^{-1}$, equivalent to 980 plants $\mathrm{m}^{-2}$, for bean cultivars and weed species (data not shown). It is noteworthy that both black bean cultivars and hairy beggarticks showed constant dry mass production in the population of 40 plants pot $^{-1}$.

With the final population established, 40 plants pots $^{-1}$, four other experiments were conducted, from November 2013 to January 2014, to evaluate the competitiveness of bean cultivars with the hairy beggarticks, all conducted in replacement series, (40:0,30:10, 20:20, 10:30 and 0:40), and the relative proportions of plants pots ${ }^{-1}$ varied. To establish the desired populations in each treatment and to obtain uniformity of the seedlings, the seeds were previously sown in trays and later transplanted to the pots.

At 40 days after emergence (DAE), the following variables were evaluated: leaf area (LA) and dry matter of the aerial part (DM) of the crop and the weed, being this time established as they entered the reproductive stage. To determine the LA, a portable CI-203 BioScence LA-meter was used, quantifying the variable in all plants in each treatment. After the determination of LA, the plants were conditioned in paper bags and placed in a forced air circulation oven at $60 \pm 5^{\circ} \mathrm{C}$ until the 
material reached a constant matter to measure the DM of the species.

The data were analyzed through the method of graphical analysis of variation or relative productivity (COUSENS, 1991; BIANCHI; FLECK; LAMEGO, 2006). This procedure, also known as the conventional method for substitutive experiments, consists in the construction of a diagram based on the relative (PR) and total (PRT) yields or variations. When the PR result is a straight line, it means that the species' ability is equivalent. If PR results in a concave line, it indicates that there is damage in the growth of one or both species. On the contrary, if the PR shows convex line, there is benefit in the growth of one or both species. When the PRT is equal to unit 1 (straight line), competition occurs for the same resources; If it is greater than 1 (convex line), competition is avoided. If the PRT is less than 1 (concave line), there is a mutual loss of growth (COUSENS, 1991; RUBIN et al., 2014).

Relative competitiveness (RC), relative clustering coefficient (K) and aggressiveness (A) were also calculated. The RC represents the comparative growth of common bean cultivars $(\mathrm{X})$ in relation to the hairy beggarticks competitor $(\mathrm{Y}) ; \mathrm{K}$ indicated the relative dominance of one species over the other, and A indicates which species was the most aggressive. Thus, the $\mathrm{RC}, \mathrm{K}$ and $\mathrm{A}$ indices indicate which species is most competitive, considering that the joint interaction indicates with more security the species' competitivity (COUSENS, 1991). The bean cultivars $X$ were more competitive than the hairy beggarticks $\mathrm{Y}$ when $\mathrm{CR}>1, \mathrm{~K}_{\mathrm{x}}>\mathrm{K}_{\mathrm{y}}$ and $\mathrm{A}>0$; On the other hand, the black-picker $\mathrm{Y}$ was more competitive than the bean cultivars $\mathrm{X}$ when $\mathrm{CR}<1, \mathrm{~K}_{\mathrm{x}}<\mathrm{K}_{\mathrm{y}}$ and A $<0$ (HOFFMAN; BUHLER, 2002). To calculate these indexes, the proportions 50:50 of the species involved in the experiment (beans and hairy beggarticks) were used, using the equations: $\mathrm{CR}=\mathrm{PR}_{\mathrm{x}} / \mathrm{PR}_{\mathrm{y}} ; \mathrm{K}_{\mathrm{x}}=\mathrm{PR}_{\mathrm{x}} /\left(1-\mathrm{PR}_{\mathrm{x}}\right)$; $\mathrm{K}_{\mathrm{y}}=\mathrm{PR}_{\mathrm{y}} /\left(1-\mathrm{PR}_{\mathrm{y}}\right) ; \mathrm{A}=\mathrm{PR}_{\mathrm{x}}-\mathrm{PR}_{\mathrm{y}}$, according to Cousens and O'Neill (1993).

The procedure of statistical analysis of the productivity or relative variation included the calculation of the differences for PR (DPR), obtained in proportions 25,50 and $75 \%$, in relation to the values belonging to the hypothetical line in the respective proportions, that is, 0,$25 ; 0.50$ and 0.75 for PR (BIANCHI; FLECK; LAMEGO, 2006). The " $t$ " test was used to test the differences related to DPR, PRT, RC, K and A indexes (HOFFMAN; BUHLER, 2002). It was considered as null hypothesis, to test the differences of DPR and A, that the means were equal to zero $(\mathrm{Ho}=0)$; For PRT and $\mathrm{RC}$, that the averages were equal to one $(\mathrm{Ho}=1)$;
And, for $\mathrm{K}$, that the means of the differences between $\mathrm{K}_{\mathrm{x}}$ and $\mathrm{K}_{\mathrm{y}}$ were equal to zero $\left[\mathrm{Ho}=\left(\mathrm{K}_{\mathrm{x}}-\mathrm{K}_{\mathrm{y}}\right)=0\right]$. The criterion for considering the PR and PRT curves different than the hypothetical lines was that, at least in two proportions, significant differences occurred by the "t" test (BIANCHI; FLECK; LAMEGO, 2006). Likewise, for $\mathrm{RC}, \mathrm{K}$ and $\mathrm{A}$, the existence of differences in competitiveness was considered when, in at least two of them, there was a significant difference by the " $t$ " test.

The results obtained for LA and DM, expressed in average values per treatment, were submitted to variance analysis by the $F$ test and being significant, the averages of the treatments were compared by the Dunnett test, considering the monocultures as controls in these comparisons. In all statistical analysis was adopted the significance of $\mathrm{p} \leq 0.05$.

\section{RESULTS AND DISCUSSION}

The graphical results show that, for the combinations of plants of the black bean cultivars BRS Campeiro, IPR Uirapuru, SCS204 Predileto and BRS Supremo with the biotype of hairy beggarticks (competitor), the four cultivars showed similarities when in competition with the weed species, with differences for the variables LA and DM in the proportions of plants tested. In relation to PRT, there were differences between the expected and estimated values for all studied variables, which presented mean values lower than 1 for FA and DM in all combinations of crop and competitor plant proportions (Figures 2 and 3). These PRT results of concave lines and values lower than 1 , allow to infer that competition occurred between the bean and the hairy beggarticks by the same resources present in the environment. According to Rubin et al. (2014), when PRT $<1$, there is mutual antagonism between species that are competing for the resources of the environment.

The presence of concave lines in all simulations indicated that there was competition for the same resources in the environment, with mutual injury to the growth of both the crop and the competitor (RUBIN et al., 2014). These losses are observed even in the smallest proportions of the weed species, which indicates that this can cause damage to the crop even in low population, as observed in the barley culture under the influence of ryegrass (GALON et al., 2011) or soybean in the presence of radish (BIANCHI; FLECK; LAMEGO, 2006). 

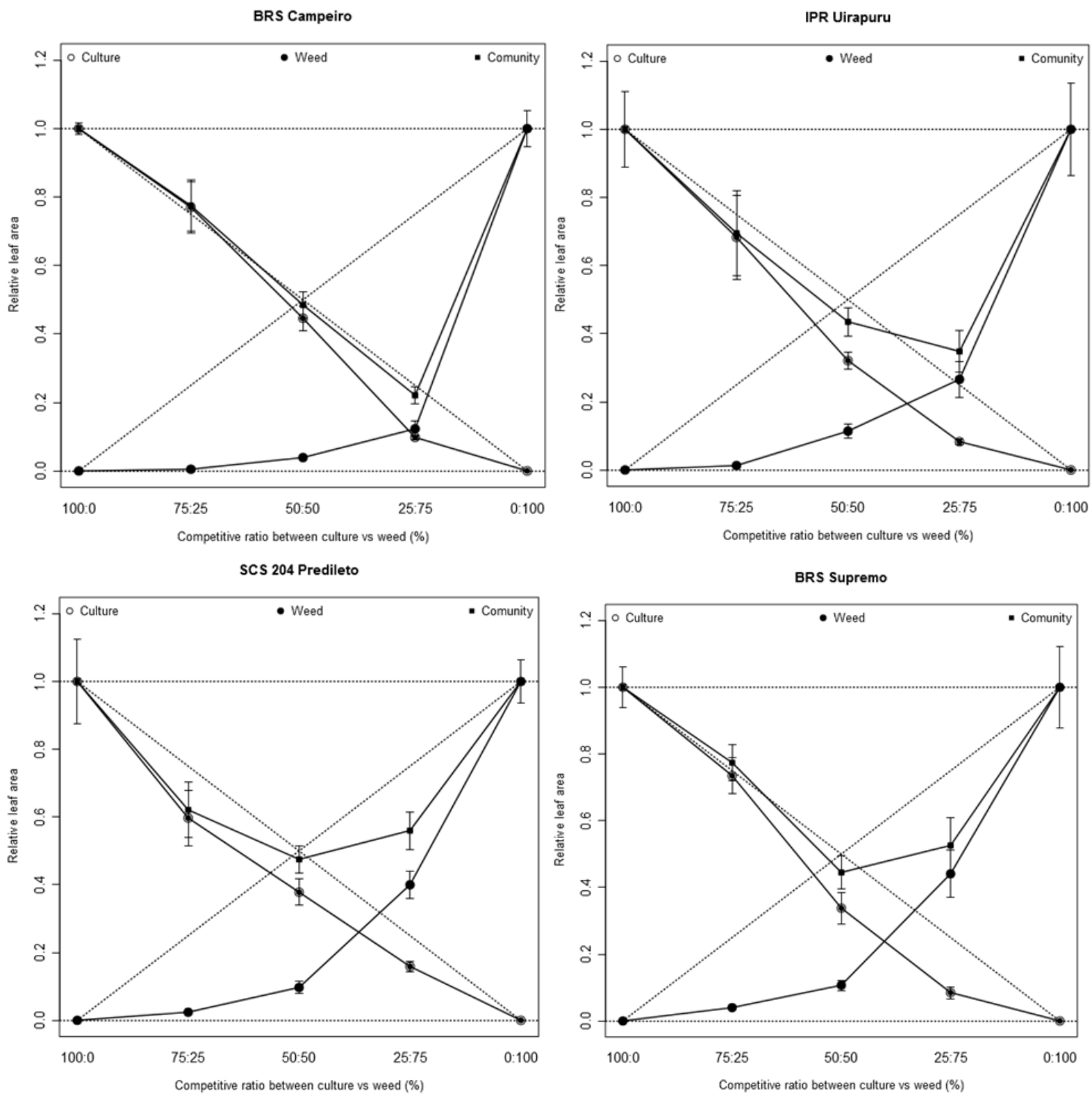

Figure 2. Relative (RLA) and total leaf area (TLA) of the black bean and hairy beggarticks competitor cultivars; $\left({ }^{\bullet}\right)$ RLA

of bean cultivar $(\mathrm{X}),\left(^{\bullet}\right)$ competitor RLA (Y) and ( ) TRLA. Dashed lines refer to hypothetical relative productivities when there is no interference of one species over another. The standard errors are shown between the repetitions of each observed value.

In all the evaluated simulations, the species did not differ between the two variables (Figures 2 and 3), except for LA when the IPR Uirapuru and BRS Supremo cultivars, in the proportion of 25:75 the culture was more competitive than the weed (Figure 2). In this way it cannot be established that there was more competition of one or another species, since in general for all the variables tested, similar behavior occurred in the dispute over the resources of the environment.

Bean cultivars presented higher relative growth than hairy beggarticks in all proportions tested (Figures 2 and 3), but they contributed little to PRT. The probable cause of the bean presents higher relative growth than the hairy beggarticks, and has been more competitive may be related to the population of plants in the association between culture and competitor, since the weeds present a greater competitive ability when in high populations and not on an individual basis, as is the case with the cultures (RIGOLI et al., 2008; AGOSTINETTO et al., 2013; GALON et al., 2015). 

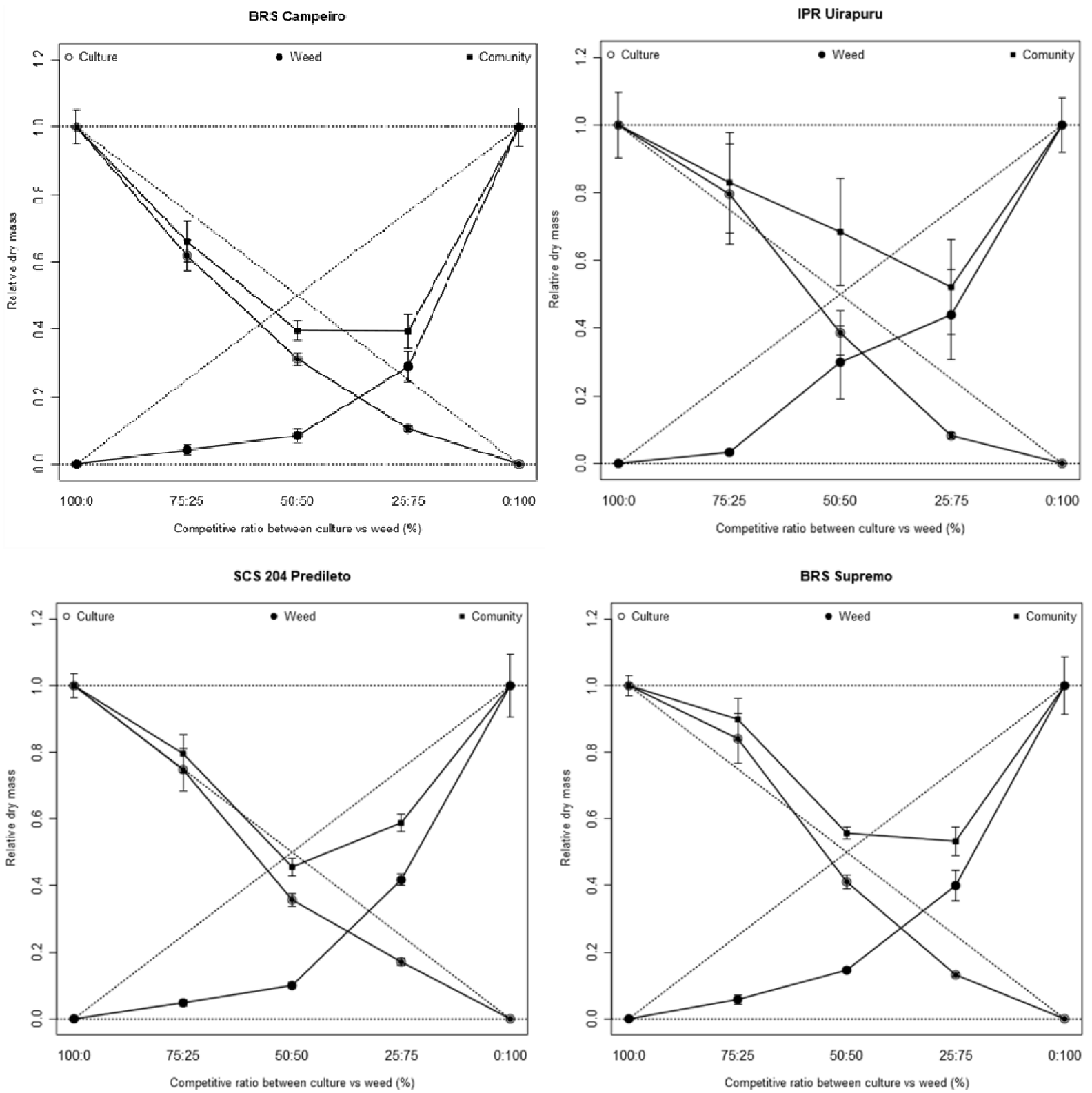

Figure 3. Aerial $(\mathrm{ADM})$ and total $(\mathrm{TDM})$ dry matter of black bean and hairy beggarticks competitor cultivars; $\left({ }^{\bullet}\right)$ ADM

of common bean $(\mathrm{X}),\left(^{\bullet}\right)$ competitor $\mathrm{ADM}(\mathrm{Y})$ and $\left({ }^{-}\right)$TRDM. Dashed lines refer to hypothetical relative productivities when there is no interference of one species over another. The standard errors are shown between the repetitions of each observed value.

It is also worth noting that, in substitutive experiments, there is little evidence of qualitative changes due to population growth, that is, the dominance of one species over the other rarely changes with population change (COUSENS; O'NEILL, 1993). Corroborate to the results observed in the present study, those verified by Agostinetto et al. (2008); Fleck et al. (2008); Galon et al. (2011) and Galon et al. (2015). However, contradictory results were verified by Agostinetto et al. (2013) when they verified differentiated behavior in the rice and soybean competition with tropical crabgrass, with the crops being more competitive than the weed, occurring differences among the species in the competition.

The results show that there were differences in PR of bean cultivars when competing with the hairy beggarticks, relative to the respective hypothetical lines, in at least two proportions of plants, according to the results expressed by standard errors (Figures 2 and 3). According to Bianchi, Fleck and Lamego (2006), to be significant at least two proportions of plants should differ, and differences between the studied and expected lines for LA and DM were verified in all proportions evaluated. It was observed in the present study that neither the crop nor the hairy beggarticks presented a greater competitive ability, occurring damages to the growth 
of the species in the community, especially the bean, since the weeds normally in agricultural areas appear in populations superior to those of the cultivated plants and in most situations are considered as more competitive in the use of resources available in the environment (BIANCHI; FLECK; LAMEGO, 2006).

The morphological variables LA and DM of the bean cultivars were reduced when they competed with the hairy beggarticks in all proportions of plants in the association (Table 1). The higher the proportion of the competitors in the association with the cultivars, the greater the damage to the crop variables. In the hairy beggarticks, it was observed a reduction in the LA and the DM, when in an equal or smaller proportion of plants, compared to the bean cultivars.

Studies have shown that damage to crop and weed growth may occur when they are in competition in a certain community (FLECK et al., 2008; RIGOLI et al., 2008; GALON et al., 2011). The lower values of DM accumulation show the high interspecific competition, in which the species compete for the same resources of the environment, as Barroso, Yamauti and Alves (2010) observed when evaluating the interference among weed species in bean cultivars. In the present study, the crop was well distributed, which increases its competitive ability, while the distribution in lines, generally used in the field, increases the damage caused by the weed community (DUSABUMUREMYI; NIYIBIGIRA; MASHINGAIDZE, 2014).

The results demonstrate for the variables LA and DM that the highest averages for treatment of the crop or even the hairy beggarticks were obtained when they were present in smaller populations in the association in all the combinations (Table 1). Thus, interspecific competition is found to be less damaging to both species than intraspecific competition. By working with wheat in the presence of ryegrass (RIGOLI et al., 2008), rice and soy $\mathrm{x}$ tropical crabgrass (AGOSTINETTO et al, 2013), wheat $x$ radish (COSTA; RIZZARDI, 2015) (RIGOLI et al., 2008) and rice in competition with northern jointvetch (GALON et al., 2015) similar effects to those in the present study were observed. It was observed that the values of LA and DM of the bean cultivars in the proportions of each mixture $(25,50$ and $75 \%)$ with those obtained in monoculture $(100 \%)$, that the interspecific competition in all the species involved in the association (bean $\mathrm{x}$ hairy beggarticks) were more expressive, with the highest averages by crop plants and weeds when they occurred in larger populations (Table 1). Corroborate with the results of the present work those found by Bianchi, Fleck and Lamego (2006) when evaluating soybean and radish; Fleck et al., (2008) studying rice $\mathrm{x}$ red rice; Agostinetto et al. (2008) when working with rice $x$ cockspur grass and Agostinetto et al., (2013) when researching rice and soybean $\mathrm{x}$ tropical crabgrass. The competition affects quantitatively and qualitatively the production, since it modifies the efficiency of the use of the resources of the environment, like water, light, $\mathrm{CO}_{2}$ and nutrients (BIANCHI; FLECK; LAMEGO, 2006), establishing itself between the culture and the plants of other species existing on site. It should be noted that in a plant community there is a benefit in the competition for resources for those that establish themselves first, or for the intrinsic characteristics of each cultivar as to the competitive ability (stature, speed of growth, number of tills, among others). In the present study, no major differences were observed between bean cultivars in competition with hairy beggarticks, even though they present genetic differentiation. This fact stems from the fact that in the field studies it has the influence of several biotic and abiotic factors and that this can alter the cultivars in a differentiated manner, so that one can have a greater importance of the genetic differentiations existing in each cultivar, which is not observed in a greenhouse, because the environment is controlled and there is less pressure from foreign agents.

When sowing crops in association with weeds, with variation in the proportion of plants, crops usually have an advantage over relative productivity, thus demonstrating that intraspecific competition exceeds interspecific competition (BIANCHI; FLECK; LAMEGO, 2006). Similar results occurred when wheat competed with ryegrass (RIGOLI et al., 2008), barley when infested by ryegrass (GALON et al., 2011) and rice in the presence of northern jointvetch (GALON et al., 2015). 
Table 1. Responses of the bean cultivars BRS Campeiro, IPR Uirapuru, SCS204 Predileto and BRS Supremo to hairy beggarticks interference for leaf area and shoot dry matter (DM), at 40 days after emergence.

\begin{tabular}{|c|c|c|}
\hline Plants proportion (Bean: Hairy beggarticks) & Leaf area $\left(\mathrm{cm}^{2}\right.$ treatment $\left.^{-1}\right)$ & Dry matter $\left(\mathrm{g}_{\text {treatment }}{ }^{-1}\right)$ \\
\hline \multicolumn{3}{|c|}{ BRS Campeiro Cultivar } \\
\hline 100:0 (C) & 33141.4 & 35.0 \\
\hline $75: 25$ & 3401.8 & $28.9^{*}$ \\
\hline $50: 50$ & $2957.6^{*}$ & $21.8^{*}$ \\
\hline $25: 75$ & $1295.3^{*}$ & $14.7 *$ \\
\hline CV $(\%)$ & 17.1 & 14.3 \\
\hline \multicolumn{3}{|c|}{ Hairy beggarticks Competitor } \\
\hline $0: 100(\mathrm{C})$ & 18470.9 & 6.7 \\
\hline $25: 75$ & $3532.6 *$ & $2.5^{*}$ \\
\hline $50: 50$ & $1665.8 *$ & $1.1^{*}$ \\
\hline $75: 25$ & $464.2^{*}$ & $1.1^{*}$ \\
\hline $\mathrm{CV}(\%)$ & 21.8 & 28.6 \\
\hline \multicolumn{3}{|c|}{ IPR Uirapuru Cultivar } \\
\hline 100:0 (C) & 6028.4 & 38.5 \\
\hline $75: 25$ & 5485.9 & 40.9 \\
\hline $50: 50$ & $3866.1 *$ & $29.7 *$ \\
\hline $25: 75$ & $1989.4 *$ & $12.7 *$ \\
\hline CV $(\%)$ & 32.2 & 36.9 \\
\hline \multicolumn{3}{|c|}{ Hairy beggarticks Competitor } \\
\hline $0: 100(\mathrm{C})$ & 16056.6 & 4.6 \\
\hline $25: 75$ & $5692.8 *$ & $2.7 *$ \\
\hline $50: 50$ & $3663.8 *$ & $2.7 *$ \\
\hline $75: 25$ & $803.7 *$ & $0.6^{*}$ \\
\hline $\mathrm{CV}(\%)$ & 43.8 & 56.7 \\
\hline \multicolumn{3}{|c|}{ SCS204 Predileto Cultivar } \\
\hline 100:0 (C) & 4274.7 & 28.3 \\
\hline $75: 25$ & 3403.1 & 28.2 \\
\hline $50: 50$ & $3230.2 *$ & $20.2^{*}$ \\
\hline $25: 75$ & $2723.4 *$ & $19.4^{*}$ \\
\hline CV $(\%)$ & 26.9 & 14.5 \\
\hline \multicolumn{3}{|c|}{ Hairy beggarticks Competitor } \\
\hline $0: 100(\mathrm{C})$ & 13077.6 & 8.1 \\
\hline $25: 75$ & $6982.7 *$ & $4.5^{*}$ \\
\hline $50: 50$ & $2540.6^{*}$ & $1.6^{*}$ \\
\hline $75: 25$ & $1265.3 *$ & $1.6^{*}$ \\
\hline CV $(\%)$ & 22.8 & \\
\hline \multicolumn{3}{|c|}{ BRS Supremo Cultivar } \\
\hline 100:0 (C) & 5884.2 & 30.6 \\
\hline $75: 25$ & 5763.3 & 34.4 \\
\hline $50: 50$ & $3980.9^{*}$ & $25.2 *$ \\
\hline $25: 75$ & $2002.5^{*}$ & $16.2 *$ \\
\hline CV $(\%)$ & 23.0 & 14.9 \\
\hline \multicolumn{3}{|c|}{ Hairy beggarticks Competitor } \\
\hline $0: 100(\mathrm{C})$ & 11394.8 & 5.8 \\
\hline $25: 75$ & $6701.3 *$ & $3.1 *$ \\
\hline $50: 50$ & $2436.1 *$ & $1.7 *$ \\
\hline $75: 25$ & $1814.6^{*}$ & $1.3 *$ \\
\hline CV (\%) & 36.3 & 25.9 \\
\hline
\end{tabular}

*Average differs from control (C) by Dunnett test $(\mathrm{p} \leq 0.05)$. 
The growth of bean cultivars exceeded that of the hairy beggarticks, as indicated by the CR index (greater than 1) for the two studied variables, LA and DM (Table 2). The relative dominance of black beans on weed expressed by index $\mathrm{K}$ $\left(\mathrm{K}_{\text {bean }}>\mathrm{K}_{\text {Hairy beggarticks }}\right)$ was also observed, and that the crop is more competitive than the weed according to the competitiveness index (positive A). In all comparisons, there were differences in at least two indexes (BIANCHI; FLECK; LAMEGO, 2006) between bean cultivars and hairy beggarticks, which shows that both are not equivalent in terms of competition for environmental resources, highlighting the bean being more competitive than the weed. Using the three indices to define competitiveness, it was verified that cultivated sorghum was more competitive than Sorghum halepense (HOFFMAN; BUHLER, 2002), that radish was more competitive than soybean genotypes (BIANCHI; FLECK; LAMEGO, 2006); Rice-grass predominated in relation to irrigated rice (AGOSTINETTO et al., 2008). When evaluating the competitive ability of bean infested by alexandergrass (PASSINI; CHRISTOFFOLETI; YADA, 2003) and with different species of Amaranthus (CARVALHO; CHRISTOFFOLETI, 2008), it was also verified that the culture had a higher competitive ability than weeds.

Table 2. Competitivity indexes between bean cultivars and hairy beggarticks $(\mathrm{P})$, expressed as relative competitiveness (RC), relative grouping $(\mathrm{K})$ and competitiveness (A) coefficients, obtained in experiments conducted in substitute series at 40 DAE.

\begin{tabular}{lcccc}
\hline Culture: Weed & RC & $\mathrm{K}_{\mathrm{xBean}}$ & $\mathrm{K}_{\mathrm{y} \text { Hairy beggarticks }}$ & $\mathrm{A}$ \\
\hline \multicolumn{7}{c}{ Leaf area } \\
\hline BRS Campeiro x Hairy beggarticks & $11.93( \pm 1.37)^{*}$ & $0.83( \pm 0.11)^{*}$ & $0.04( \pm 0.01)$ & $0.41( \pm 0.03)^{*}$ \\
IPR Uirapuru x Hairy beggarticks & $2.98( \pm 0.32)^{*}$ & $0.48( \pm 0.05)^{*}$ & $0.13( \pm 0.02)$ & $0.21( \pm 0.02)^{*}$ \\
SCS204 Predileto x Hairy beggarticks & $4.35( \pm 1.00)^{*}$ & $0.63( \pm 0.10)^{*}$ & $0.11( \pm 0.02)$ & $0.28( \pm 0.04)^{*}$ \\
BRS Supremo x Hairy beggarticks & $3.39( \pm 0.64)^{*}$ & $0.53( \pm 0.11)^{*}$ & $0.12( \pm 0.02)$ & $0.23( \pm 0.05)^{*}$ \\
\hline \multicolumn{7}{c}{ Shoot Dry matter } & & \\
\hline BRS Campeiro x Hairy beggarticks & $5.75( \pm 2.82)$ & $0.45( \pm 0.04)^{*}$ & $0.09( \pm 0.02)$ & $0.23( \pm 0.03)^{*}$ \\
IPR Uirapuru x Hairy beggarticks & $1.87( \pm 0.54)^{*}$ & $0.70( \pm 0.22)$ & $0.54( \pm 0.25)$ & $0.09( \pm 0.09)^{*}$ \\
SCS204 Predileto x Hairy beggarticks & $3.64( \pm 0.26)^{*}$ & $0.56( \pm 0.04)^{*}$ & $0.11( \pm 0.01)$ & $0.25( \pm 0.01)^{*}$ \\
BRS Supremo x Hairy beggarticks & $2.84( \pm 0.23)^{*}$ & $0.70( \pm 0.29)^{*}$ & $0.06( \pm 0.01)$ & $0.26( \pm 0.02)^{*}$ \\
\hline
\end{tabular}

*Significant difference by t-test $(\mathrm{p} \leq 0.05)$. Values in parentheses represent the standard error of the average. $\mathrm{K}_{\mathrm{x}}$ and $\mathrm{K}_{\mathrm{y}}$ are the relative clustering coefficients of bean cultivar and Hairy beggarticks competitor, respectively.

In most situations, the crop may present a greater competitive ability than the weed in an isolated way because the effect of the weed species is not due to its greater individual competition, but mainly due to the combined effect of its total population of plants (BIANCHI; FLECK; LAMEGO, 2006). However, in some studies, the weed showed a greater competitive ability than the irrigated rice, living with: rice grass (AGOSTINETTO et al., 2008), Red rice (FLECK et al., 2008) and northern jointvetch (GALON et al., 2015); barley x ryegrass (GALON et al., 2011); and soybean $\mathrm{x}$ radish (BIANCHI; FLECK; LAMEGO, 2006). It is also emphasized that in a plant community there is a benefit in the competition for resources for those that establish themselves first, or for the intrinsic characteristics of each cultivar or hybrid in relation to the competitive ability (height, growth speed, spatial distribution, leaf area index , number of tillers, leaf area, dry mass, among others) and thus smaller amounts of resources will be available in the environment which causes increased damage to the competitor or crop (CARVALHO; CHRISTOFFOLETI, 2008; AGOSTINETTO et al., 2013).
Interpreting together the graphs of relative variables and their significance in relation to the equivalent values (Figures 2 and 3), the morphological variables (Tables 1) and the competitiveness indexes (Table 2) showed that there is a negative interaction between the species. However, in this case, the Hairy beggarticks competitor suffered more damage when compared to bean cultivars that were more competitive than the weed. Thus, the differences in competitiveness of the evaluated species may be due to the fact that they present distinct morphophysiological characteristics or exploit different environmental resources. Or because of the fact that in plant communities two responses may occur to the increase in plant density: mortality, which affects the number of individuals and plasticity that affects the size of the survivors, and consequently the production of LA and DM (ZANIN; SATTIN, 1988). Similar results were observed in studies evaluating the competitiveness of bean $x$ alexandergrass (PASSINI; CHRISTOFFOLETI; YADA, 2003), bean $\mathrm{x}$ Amaranthus (CARVALHO; CHRISTOFFOLETI, 2008), soybean $\mathrm{x}$ radish (BIANCHI; FLECK; LAMEGO, 2006), rice and soybean $x$ tropical 
crabgrass (AGOSTINETTO et al., 2013), northern jointvetch $\mathrm{x}$ rice (GALON et al., 2015). Knowledge of the dynamics and competitiveness of plants, especially beans and hairy beggarticks, is fundamental to the decision-making process of weed control in a given population, which will not cause negative interference on the crop.

\section{CONCLUSION}

There was competition between bean cultivars (BRS Campeiro, IPR Uirapuru, SCS204 Predileto and BRS Supremo) in the presence of hairy beggarticks, both negatively affected, regardless of the proportion of plants.

Bean cultivars BRS Campeiro, IPR Uirapuru, SCS204 Predileto and BRS Supremo presented lower relative losses, showing superiority in competitive ability in relation to the weed.

Interspecific competition is less damaging to both species involved than intraspecific competition.

\section{ACKNOWLEDGEMENTS}

To CNPq and FAPERGS, for the financial support for the research (processes No. 482144/2012-2/CNPq and 12/2265-3/FAPERGS) and for scholarships.

\section{REFERENCES}

AARSSEN, L. W. Ecological combining ability and competitive combining ability in plants: Toward a general evolutionary theory of coexistence in systems of competition. The American Naturalist, Chicago, v. 122, n. 6, p. 707-731, 1983.

AGOSTINETTO, D. et al. Competitividade relativa entre cultivares de arroz irrigado e biótipo de capim-arroz (Echinochloa spp.). Planta Daninha, Viçosa, v. 26, n. 4, p. 757-766, 2008.

AGOSTINETTO, D. et al. Habilidade competitiva relativa de milhã em convivência com arroz irrigado e soja. Pesquisa Agropecuária Brasileira, Brasília, v. 48 , n. 10 , p. 1315-1322, 2013.

ANDRADE, C. A. B. et al. Efeito da competição com plantas daninhas em diferentes espaçamentos sobre o rendimento de três cultivares de feijão (Phaseolus vulgaris L.). Ciência e Agrotecnologia, Lavras, v. 23, n. 3, p. 529-539, 1999.

BARROSO, A. A. M.; YAMAUTI M. S.; ALVES P. L. C. A.; Interferência entre espécies de planta daninha e duas cultivares de feijoeiro em duas épocas de semeadura. Bragantia, Campinas, v. 69, n. 3, p. 609-616, 2010.

BIANCHI, M. A.; FLECK, N. G.; LAMEGO, F. P.; Proporção entre plantas de soja e plantas competidoras e as relações de interferência mútua. Ciência Rural, Santa Maria, v. 36, n. 5, p. 1380-1387, 2006.

CARVALHO, S. J. P.; CHRISTOFFOLETI, P. J. Competition of Amaranthus species with dry bean plants. Scientia Agricola, Piracicaba, v. 65, n. 3, p. 239-245, 2008.

CHRISTOFFOLETI, P. J.; VICTÓRIA FILHO, R. Efeitos da densidade e proporção de plantas de milho (Zea mays L.) e caruru (Amaranthus retroflexus L.) em competição. Planta Daninha, Botucatu, v. 14, n. 1, p. 42-47, 1996.

CIESLIK, L. F.; VIDAL, R. B.; TREZZI, M. M. Fomesafen toxicity to bean plants as a function of the time of application and herbicide dose. Acta Scientiarum. Agronomy, Maringá, v. 36, n. 3, p. 329-334, 2014.

COSTA, L. O da.; RIZZARDI, M. A. Competitive ability of wheat in association with biotypes of Raphanus raphanistrum L. resistant and susceptible to ALS-inhibitor herbicides. Ciência e Agrotecnologia, Lavras, v. 39, n. 2, p. 121-130, 2015.

COUSENS, R. Aspects of the design and interpretation of competition (interference) experiments. Weed Technology, Champaign, v. 5, n. 3, p. 664-673, 1991.

COUSENS, R.; O’NEILL, M. Density dependence of replacement series experiments. Oikos, Wiley, v. 66, n. 2, p. 347-352, 1993.

CURY, J. P. et al. Eficiência nutricional de cultivares de feijão em competição com plantas daninhas. Planta Daninha, Viçosa, v. 31, n. 1, p. 79-88, 2013.

DUSABUMUREMYI, P.; NIYIBIGIRA, C.; MASHINGAIDZE, A. B. Narrow row planting increases yield and suppresses weeds in common bean (Phaseolus vulgaris L.) in a semi-arid agro-ecology of Nyagatare, Rwanda. Crop Protection, Chicago, v. 64, n. 1, p. 13-18, 2014.

ELIAS, H. T. Informações técnicas para o cultivo de feijão na Região Sul brasileira. 2. ed. Florianópolis, SC: EPAGRI, 2012. 157 p.

EMPRESA BRASILEIRA DE PESQUISA AGROPECUÁRIA - EMBRAPA. Centro Nacional de Pesquisa Agropecuária de Solos (Brasília, DF). 
Sistema brasileiro de classificação de solos. Brasília: Embrapa Produção de Informação; Brasília, DF: Embrapa Solos, 2013. 154 p.

FLECK, N. G. et al. Competitividade relativa entre cultivares de arroz irrigado e biótipo de arroz-vermelho. Planta Daninha, Viçosa, v. 26, n. 1, p. 101-111, 2008.

GALON, L. et al. Competitividade relativa de cultivares de arroz irrigado com Aeschynomene denticulata. Bragantia, Campinas, v. 74, n. 1, p. 67-74, 2015.

GALON, L. et al. Habilidade competitiva de cultivares de cevada convivendo com azevém. Planta Daninha, Viçosa, v. 29, n. 4, p. 771-781, 2011.

GOLDBERG, D. E.; LANDA, K. Competitive effect and response: Hierarchies and correlated traits in the early stages of competition. Journal of Ecology, London, v. 79, n. 4, p. 1013-1030, 1991.

HOFFMAN, M. L.; BUHLER, D. D. Utilizing Sorghum as a functional model of crop weed competition. I. Establishing a competitive hierarchy. Weed Science, Lawrence, v. 50, n. 4, p. 466-472, 2002.

INSTITUTO NACIONAL DE METEOROLOGIA INMET. Dados Históricos. Disponível em: <http:// www.inmet.gov.br/portal/index.php? $\mathrm{r}=\mathrm{bdmep} /$ bdmep>. Acesso em: 02 de jan. 2017.

KALSING, A.; VIDAL, R. A. Nível crítico de dano de papuã em feijão-comum. Planta Daninha, Viçosa, v. 31, n. 2, p. 843-850, 2013.

MANABE, P. M. S. et al. Características fisiológicas de feijoeiro em competição com plantas daninhas. Bioscience Journal, Uberlândia, v. 30, n. 6, p. 1721-1728, 2014

MINISTÉRIO DA AGRICULTURA PECUÁRIA E ABASTECIMENTO. REGISTRO NACIONAL DE CULTIVARES - MAPA. Registro nacional de cultivares. Disponível em: <http:// extranet.agricultura.gov.br/php/snpc/cultivarweb/ cultivares_registradas.php> Acesso em: $31 \mathrm{de}$ dez. 2016.

MUNIER-JOLAIN, N. M. et al. Investigating and modelling the morphological plasticity of weeds. Field Crops Research, Gangtok, v. 155, n. 1, p. $90-98,2014$.

PASSINI, T.; CHRISTOFFOLETI, P. J.; YADA, I. F. U. Competitivity of the common-bean plant relative to the weed alexandergrass [Brachiaria plantaginea (Link) Hitch.]. Scientia Agricola, Piracicaba, v. 60, n. 3, p. 259-268, 2003.

RADOSEVICH, S. R.; HOLT, J. S.; GHERSA, C. $M$. Ecology of weeds and invasive plants: relationship to agriculture and natural resource management. 3. ed. New Jersey, Estados Unidos da América: Wiley-Interscience. 2007, 472 p.

RIGOLI, R. P. et al. Habilidade competitiva relativa do trigo (Triticum aestivum) em convivência com azevém (Lolium multiflorum) ou nabo (Raphanus raphanistrum). Planta Daninha, Viçosa, v. 26, n. 1, p. 93-100, 2008.

RUBIN, R. S. et al. Habilidade competitiva relativa de arroz irrigado com arroz-vermelho suscetível ou resistente ao herbicida imazapyr + imazapic. Arquivos do Instituto Biológico, São Paulo, v. 81, n. 2, p. 173-179, 2014.

TEIXEIRA, I. R. et al. Competição entre feijoeiros e plantas daninhas em função do tipo de crescimento dos cultivares. Planta Daninha, Viçosa, v. 27, n. 2, p. 235-240, 2009.

VIDAL, R. A.; KALSING, A.; GHEREKHLOO, J. Interferência e nível de dano econômico de Brachiaria plantaginea e Ipomoea nil na cultura do feijão comum. Ciência Rural, Santa Maria, v. 40, n. 8, p. 1675-1681, 2010.

ZANIN, G.; SATTIN, M. Threshold level and seed production of velvetleaf (Abutilon theophrasti Medicus) in maize. Weed Reserch, Oxford, v. 28, n. 3, p. 347-352, 1988. 